\title{
Effect of phenolic compound extract of green tea to ameliorate the Cadmium Sulphate toxicity on the female rat kidneys
}

\author{
Zainab Ibrahim Muhammed \\ College of veterinary medicine /AL-Qadisiyauniversity
}

\begin{abstract}
In the recent years, green tea has become asubject of widely studied for its beneficial effect in the treatment and prevention of human disease. The purpose of this study was to investigate the effects of daily oral consumption of phenolic compound extract of green tea for 30 days on kidney function in female rats that exposure to Cadmium Sulphate. Female Rats (6-8 weeks) age were divided in to four groups : control group, treatment group 1 (receives $50 \mathrm{mg} / \mathrm{L}$ of Cadmium Sulphate with drinking water), treatment group2(receives $50 \mathrm{mg} / \mathrm{L}$ of cadmium sulphate and $400 \mathrm{mg} / \mathrm{kg}$ of phenolic compound of green tea) and treatment group 3(receives $400 \mathrm{mg} / \mathrm{kg}$ of phenolic compound extract of green tea).Plasma uric acid and creatinine levels were significantly increased in T1 group compared with control group and significantly decreased in T2group compared with T1 group.The study continued for 30 days and the kidneys were collected for histopathological studies.The phenolic compound extract of green tea protected kidney tissues against toxicity effect of cadmium sulphate as evidenced from amelioration of histopathological alterations and normalization of kidney biochemical parameters.
\end{abstract}

\section{Introduction}

Cadmium is widely distributed in the environment because of its many industrial application. The health risk to humans from acute and chronic cadmium exposure has been well documented.Cadmium is considered one of the toxic trace elements in the environment(Dunnick\&Fowler,1988).Cadmiumenters to blood ,kidney and liver(Bhattacharyya etal.,2000; Wu etal.,2007) as well as in the reproductive organs and also in the hypothalamus and in the pituitary gland mammals(Vargaetal.,1991).Cadmium has also been shown to affect cell physiology and growth and to induce lipid peroxidation, that is dependentonoxygen free radicals

(Lafuenteetal.,2003;Manca etal.,1991).

Cadmium enters the food chain when cadmium waste from the industrial production is disposed in the sewages and the sewages sludge is used as agricultural fertilizer .The crops bioaccumulate cadmium in roots ,tubers,leaves and other parts of the plant that used as food ,hence cadmium poisoning in human body is evident ,Ingested cadmium is stored in the renal and sex organs and cause renal dysfunction and testicular necrosis (May \&Mckinney,1981).It stimulates and binds to various biological compounds such as proteins and non proteinsulfhydral groups ,macromolecules and metallothionein(Klassenetal.,1999).Cadmium toxicity associated with several clinical complication,dysfunction,bone disease and hepatic dysfunction(Jarupetal.,2000).Renal tubular damage is probably the most common adverse effect (Goyer and Cherian ,1995 ;Jarupetal.,1998).Cadmium toxicity is dependent on dose ,duration and route of exposure .Cadmium has also been shown to inhibit the active of various pancreatic proteases (Lobetetal.,1998).Cadmium induced peroxidation caused the release of free oxygen radicals ,these free radicals cause the stimulation and destruction of sensitive macromolecules and indeed tissues (Lafuenteetal.,2000). Recently, green tea is being widely studied for its beneficial effect in the treatment and prevention of human diseases.It is considered to be anti-inflammatory anti-oxidative, anti-mutagenic and anti-carcinogenic (Liao etal.,2001;Crespy\&Williamson,2004).Tea is one of the most popular beverages world wide habitual consumption of green tea (Camellia Sinensis),green tea is a non-fermented tea and contains more catechins than black tea.Its content of certain minerals and vitamins increases the antioxidant potential of this type of tea green tea contains nearly 4000 bioactive compounds of which one third is contributed by polyphenols (Tariq etal.,2010),other compounds are alkaloids (Caffeine ,theophylline,chlorophyll,fluoride,aluminum,minerals and trace elements (Cabrera etal.,2003).Polyphenols found in green tea are mostly flavonoids , the polyphenolsa large group of plant chemicals that include the catechins are thought to be responsible for the health benefits that have traditionally been attributed to tea especially green tea (Babuetal.,2006).Major catechins are epicatechingallate (ECG),epicatechin(EC),epigallocatechin (EGC) and epigallocatechingallate (EGCG).The most active and abundant catechin in green tea is epigallocatechin -3-gallate(EGCG) (Wu and Yu,2006).Green tea has been considered a medicine and healthful beverage since ancient times, the traditional chinese medicine has recommended this plant for headaches ,body aches and pains, digestion, depression ,detoxification, as an energizer and ingeneral to prolong life, its contain three main components which act up on human health 
:xanthic bases (caffeine and theophylline),essential oils and especially polyphenolic compounds (Varnam\&Sutherland,1994).Green tea is considered a dietary source of antioxidant nutrients and rich in polyphenols (catechins and gallic acid), and also contain phytochemical compounds,these compounds could increase the GTP antioxidant potential .GTP present antioxidant activity in vitro by scavenging reactive oxygen and nitrogen species and chelating redox active transition metal ions(Kim etal.,2003;Skrzydlewsjaetal.,2002). Several studies have shown that EGCG can act in vitro as antioxidant by trapping proxyl radicals and inhibiting lipid peroxidation (Saffari\&Sadrzadeh,2004;Zhang etal.,2004).Tokunagagetal(2002) showed that green tea consumption has a lowering effect on plasma cholesterol and triglycerids levels.Moreover (Erbaetal.,2005) studied the effect of moderate intake of green tea on human healthy and they found a significant decrease in LDL cholesterol. Plasma creatinine and blood urea levels were found to be reduce by the administration of green tea polyphenols in alloxan-induced diabetic rats (Sabuetal.,2002),Clark etal.,(2004) reported that diabetic rats treated with green tea showed a significant reduction in creatinine level ,but blood urea statistically didn't change.

This experiment was designed to study the effect daily oral consumption of phenolic compounds extract of green tea for 30 days on kidney function in female rats that exposure to cadmium sulphate.

\section{1-Extraction of phenolic compound}

\section{Materials and methods}

The leaf of green tea was obtained from local market of AL-Qadisyiauniversity.Then dried and powdered ,according to Gayon method (1972),200g ram of plant powder was weight and added to $800 \mathrm{ml}$ of $2 \%$ acetic acid and extract ,the mixture was left for 24 hours in an incubator at $50 \mathrm{c}^{\circ}$,then filtered though filter paper to remove all the residual materials .The clear extracted solution treated with the same volumes of N-propanol and then saturated with $\mathrm{NaCl}$.The upper layer was separated by funnel,then dried at $45 \mathrm{c}^{\circ}$ using an incubator .

\section{2-Model:}

Twenty four (24) healthy Albino female rats of age (6-8) weeks experiment animals were housed in the animals house of college of veterinary medicine /AL-Qadisiyia university.The experiment period was one months (from 25 February 2013 t0 25 March 2013).Animals were divided in to 4 groups as 6 animals in each group as the following:

1-Control group $(\mathbf{C})$ :receives distilled water.

2-Treatment group1 (T1):receives Cadmium Sulphate with drinking water at a dose $(50 \mathrm{mg} / \mathrm{L})$.

3-Treatment group2(T2):receives Cadmium Sulphate with drinking water at a dose $(50 \mathrm{mg} / \mathrm{L})$ of and orally gavage with phenolic compound extract of green tea at a dose $(400 \mathrm{mg} / \mathrm{kg}$ of body weight).

4-Treatment group3 (T3):orally gavage with phenolic compound extract of green tea at a dose $(400 \mathrm{mg} / \mathrm{kg}$ of body weight).

\section{3- Blood collection}

Blood samples were collected from the animals after 24 hours from experimented and the blood samples were obtained by the heart puncture .The blood was centrifuge in atest tube at $5000 \mathrm{rpm}$ for 15 minutes, serum was carefully separated and stored with frozen condition .uric acid and creatinine were estimate using an automatic analyzer (Reflotron ${ }^{\circledR}$ plus system ,Roche, Germany).

\section{4-Tissue preparation}

The animals were scarified by heart puncture and kidney speciemenscollected for histological examination .Tissues samples were kept in 10\% neutral buffered formalin and the histopathological preparations was carried out according to (Luna,1968).

\section{Statistical analysis}

Result were expressed as mean \pm S.E,the differences between mean values were analyzed by using F-test and LSD , significance was considered when $\mathrm{P}<0.05$ (Schelfer,1980).

\section{Results and Discussion}

The results point out a significant increase $(\mathrm{P}<0.05)$ in uric acid $(2.121 \pm 0.061)$ and creatinine $(0.66 \pm 0.019)$ levels in $\mathrm{T} 1$ group(a group which receives $50 \mathrm{mg} / \mathrm{L}$ of Cadmium Sulphate with drinking water ) compared with control group $(1.651 \pm 0.048)$ and $(0.531 \pm 0.021)$, this is consisted with the earlier works of (Harstand\&Klaassen,2000;Aprioku,\&Obianime,2008) in which they showed that cadmium induced increase in ALP and urea ,suggest hepatic and renal toxicities respectively. Moreover,(Obianimeetal.,2011) shown that increased in creatinine and urea levels in guinea pigs that exposure to cadmium chloride because of renal toxicity and this is agreed with previous studies of (Harstand\&Klaassen ,2000; Aprioku\&Obianime,2008;Obiamine\&Robert,2009). While ,the results recorded a significant decrease uric acid $(1.886 \pm 0.008)$ and creatinine $(0.565 \pm 0.013)$ levels in $\mathrm{T} 2$ group (a group which receives $50 \mathrm{mg} / \mathrm{L}$ cadmium sulphate and $400 \mathrm{mg} / \mathrm{Kg}$ of phenolic compound extract of green tea ) compared with $\mathrm{T} 1$ group ,because the 
catechins in green tea is clearly effective in reducing oxidative stress and inflammatory reactions in kidney tissue (Choi etal.,2004).Another interpretation made by (Kwagetal.,2001) was reported that green tea catechin has been found to improve the ratio of prostaglandin I/thromboxane A2 by controlling the cyclooxygenase way of the arachidonic acid inthe microsome and glomeruli of diabetic rat kidney .(Yokozawaetal.,2005) have recently shown that the combination of green tea polyphenols (GTP) and partially hydrolysedguargum (PHGG) reduced kidney weight, level of blood urea and serum creatinine in diabetic animals.Moreover,(Silanetal.,2007) showed that green tea could help kidneys process toxins and waste products more efficiently.As well as ,Yokozawaetal.,(2005) showed that GTP and PHGG improvement of kidney weight and serum levels of urea and creatinine and creatinine clearance in diabetic rats treated with $(100 \mathrm{mg} / \mathrm{Kg})$ of GTP and $(100 \mathrm{mg} / \mathrm{Kg})$ of PHGG, (Byravetal.,2010)showed the powerful antioxidant capacity and anti inflammatory effect of green tea polyphenols.

Table (1):changes in uric acid and creatinine levels in different studied groups.

\begin{tabular}{|c|c|c|}
\hline Groups & $\begin{array}{l}\text { Uric acid } \\
(\mathbf{m g} / \mathbf{d l})\end{array}$ & $\begin{array}{l}\text { Creatinine } \\
(\mathbf{m g} / \mathbf{d l})\end{array}$ \\
\hline C & $\begin{array}{c}1.651 \pm 0.048 \\
\mathrm{a}\end{array}$ & $\begin{array}{c}0.531 \pm 0.021 \\
\mathrm{ad}\end{array}$ \\
\hline T1 & $\begin{array}{c}2.121 \pm 0.061 \\
\mathrm{~b}\end{array}$ & $\begin{array}{c}0.66 \pm 0.019 \\
\mathrm{~b}\end{array}$ \\
\hline T2 & $\begin{array}{c}1.886 \pm 0.008 \\
\mathrm{c}\end{array}$ & $\begin{array}{c}0.565 \pm 0.013 \\
\mathrm{ac}\end{array}$ \\
\hline T3 & $\begin{array}{c}1.713 \pm 0.027 \\
\mathrm{a}\end{array}$ & $\begin{array}{c}0.476 \pm 0.028 \\
\mathrm{~d}\end{array}$ \\
\hline LSD & 0.126 & 0.06 \\
\hline
\end{tabular}

- $\quad$ Results expressed as mean \pm S.E.

- Different letters refer to significant differentiations between groups at $(\mathrm{P}<0.05)$.

- Similar letters refer to significant differentiations between groups at $(\mathrm{P}<0.05)$.

- C:Control group

- T1:receivesCadmium Sulphate with drinking water at a dose

$(50 \mathrm{mg} / \mathrm{L})$.

- T2:receivesCadmium Sulphate with drinking water at a dose $(50 \mathrm{mg} / \mathrm{L})$ and orally gavage with phenolic compound extract of green tea at a dose $(400 \mathrm{mg} / \mathrm{kg}$ of body weight).

- T3:orally gavage with phenolic compound extract of green tea at a dose $(400 \mathrm{mg} / \mathrm{kg}$ of body weight)

The histopathological results of kidney sections showed ,that kidney section of the control group revealed high - cellularity normal renal convoluted tubules with normal glomeruli as in (Fig1 and Fig 2), While kidney sections of T1 group (a group which receives Cadmium Sulphate with drinking water at a dose $50 \mathrm{mg} / \mathrm{L}$ )revealed dilation of renal convoluted tubules with sever hemorrhage in the renal tissue ,sever degeneration in the endothelial cells which lining the renal convoluted tubules as in (Fig 3 and Fig 4), as well as deposition of hyaline material in the renal tissue (hyaline degeneration), this is belonged to cadmium compounds that cause kidney damage ,(Habeebuetal.,1998;Jones\&Cherian,1988) showed that cadmium caused liver ,kidney and testicular damage.

Histopathological sections of kidney in T2 group ( a group which receives Cadmium Sulphate with drinking water at a dose $50 \mathrm{mg} / \mathrm{L}$ ) and orally gavage with phenolic compound extract of green tea as a dose $400 \mathrm{mg} / \mathrm{kg}$ of body weight), showed normal glomeruli and few dilation of renal convoluted tubules which lining with normal endothelial cells ,there is tubular basophilia (tubular regeneration), no congestion and no hyaline material as in (Fig 5 and Fig 6),In the study of (Silanetal.,2007) shown the protective effect of green tea extract $(300 \mathrm{mg} / \mathrm{Kg})$ against histopathological alternations induced by gentamicin in the kidney tissues ,GTE blocked cellular inflammatory process as indicated from alleviation of perivascular edema and reduction in mononuclear leucocytes inflammatory cells infiltration and scavenging of free oxygen radicals prevent irreversible renal cell injury ,necrosis and degeneration. While,the kidney section in the T3 group(a group which orally gavage with phenolic compound extract of green tea at a dose $400 \mathrm{mg} / \mathrm{kg}$ of body weight), showed high cellularity glomeruli and normal renal convoluted tubules which lining with normal endothelial cells as in (Fig 7 and Fig 8), this group appears like control group. 


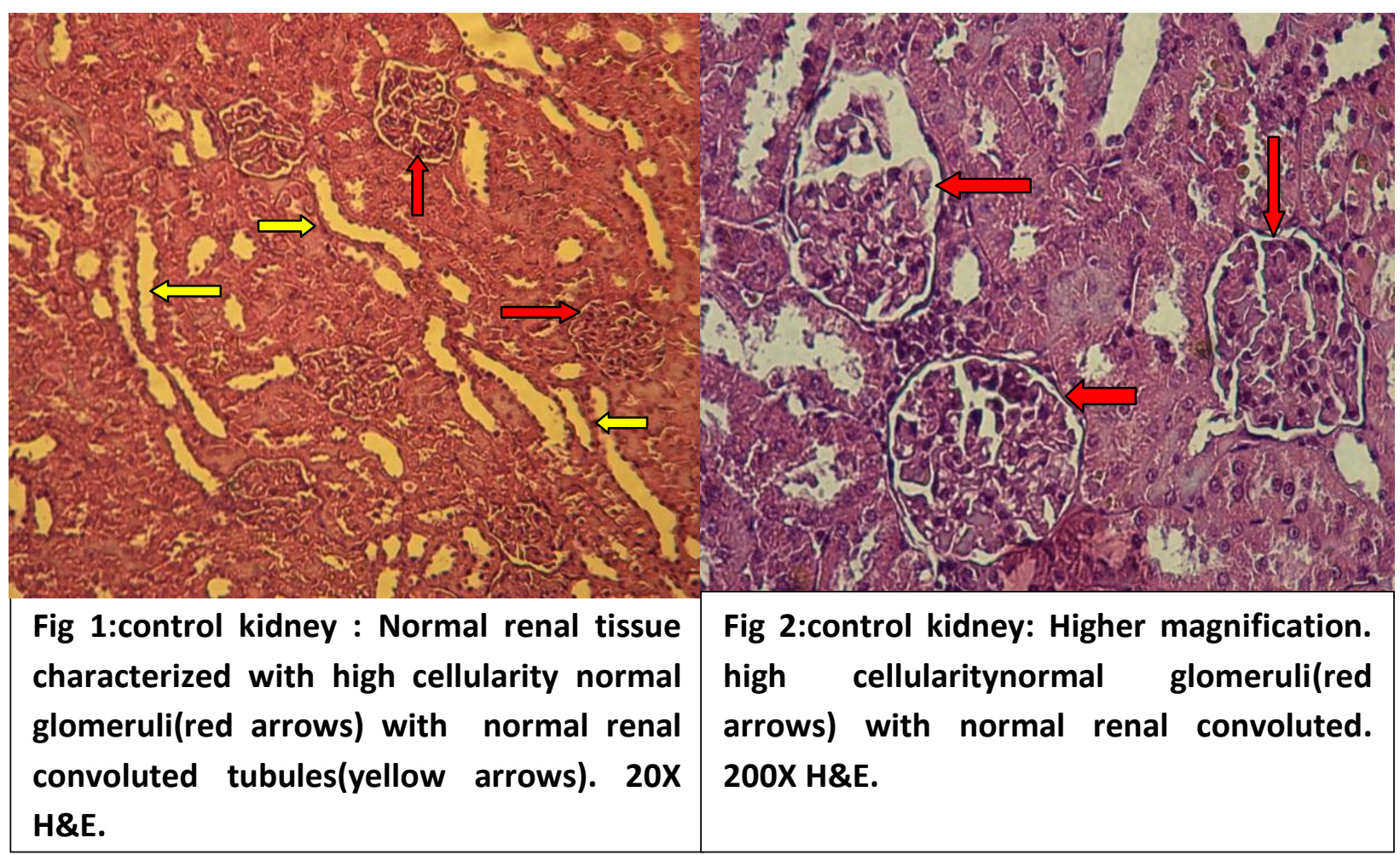

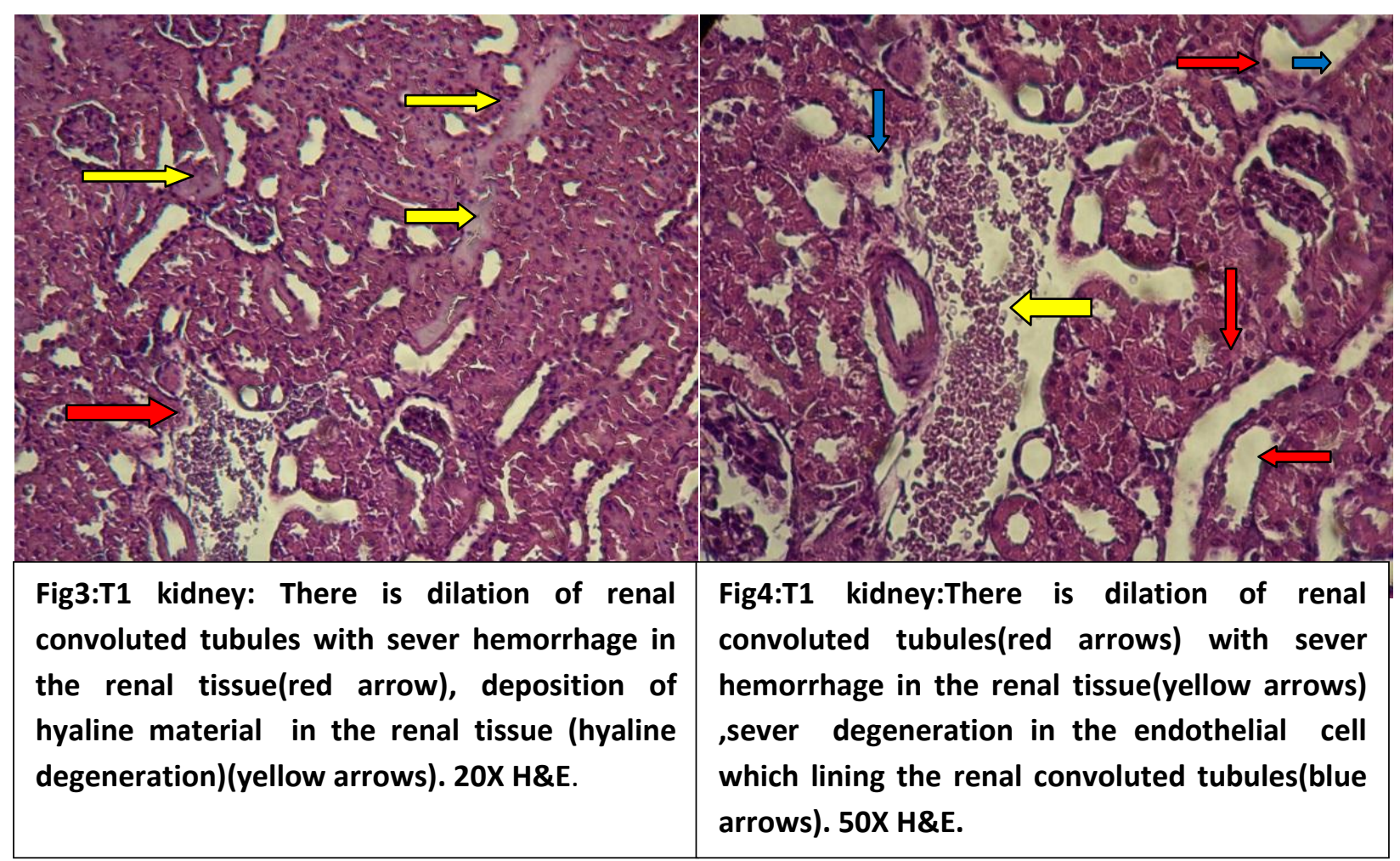




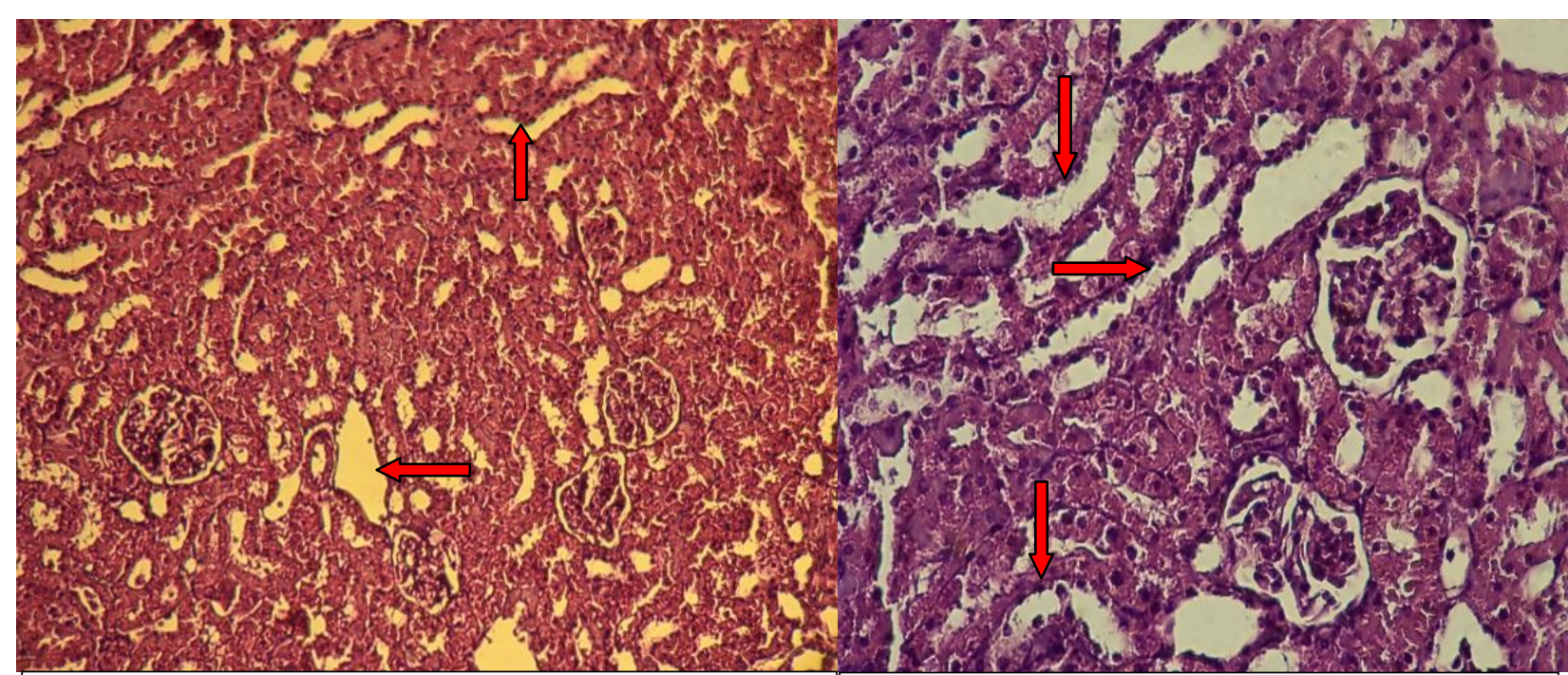

Fig5: T2 kidney:there is normal glomeruli ,few dilation of renal convoluted tubules(red arrows). There is no congestion and no hyaline material. 20X H\&E.

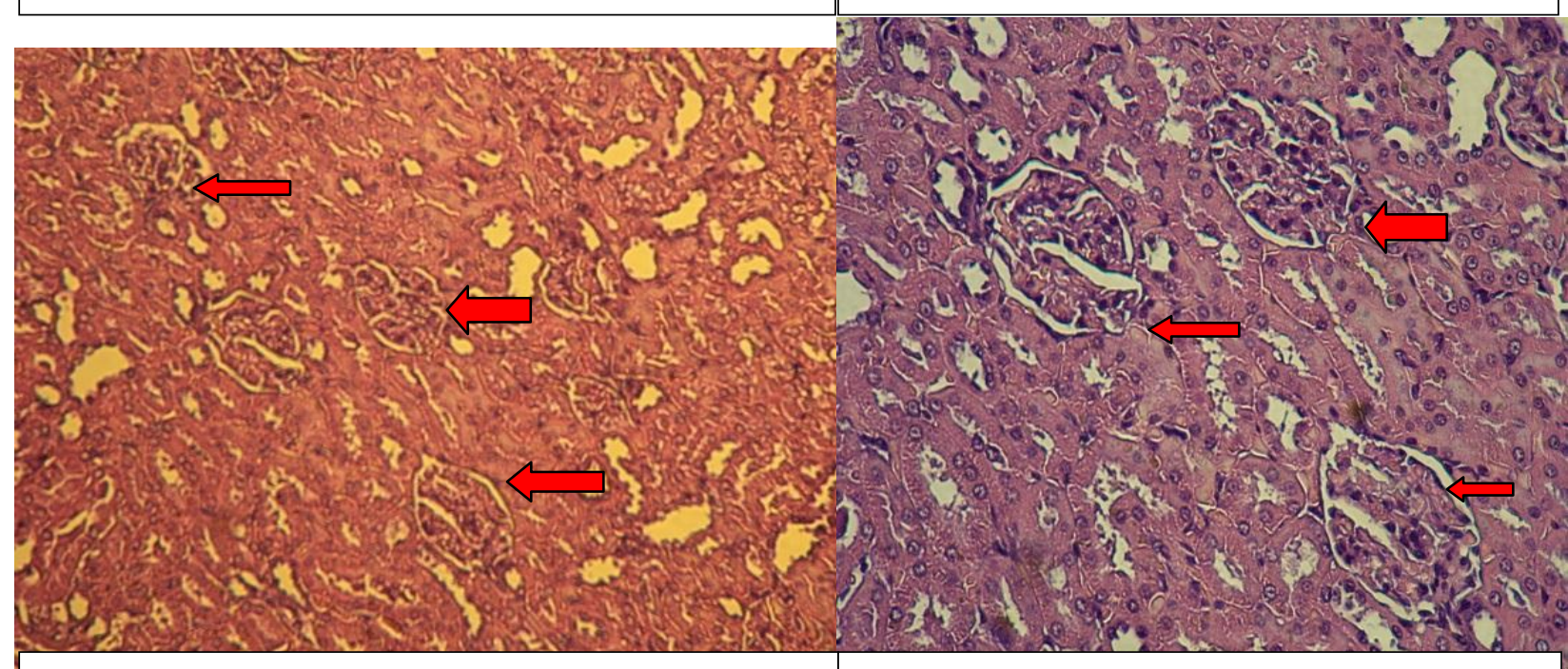

Fig 7: T3 kidney : there is high cellularity glomeruli(red arrows) ,normal renal convoluted tubules which lining with normal endothelial cells. 20X H\&E.
Fig6: T2 kidney:there is normal glomeruli ,few dilation of renal convoluted tubules which lining with normal endothelial cells. Also there is tubular basophilia (tubular regeneration)(red arrows). There is no congestion and no hyaline material. 50X H\&E.

Fig 8: T3 kidney : Higher magnification. There is high cellularity glomeruli(red arrows), normal renal convoluted tubules which lining with normal endothelial cells. 50X H\&E. 


\section{References}

[1]. Aprioku, J.S\&Obianime ,A. W.(2008). Effects of the aqueous leaf extract of Ocimumgratissimum Linn.(Lamiaceae) on some cadmium -induced biochemical changes in maleguinea-pigs. West .Afr .J. Pharmacol .Drug Res.,P.24.

[2]. Babu,P.V.;Sabitha,K.E.\&Shyamaladevi,C.S.(2006).Green tea impedes dyslipidemia ,lipid peroxidation,protein glycation andameliorates $\mathrm{Ca}^{+2}-\mathrm{ATPase}$ and $\mathrm{Na}^{+} / \mathrm{K}^{+}$-ATPase activity in theheart of streptozotocin -diabetic rats. Chem. Biol. Interact., 162(2):157-164.

[3]. Bhattacharyya,M.H.;Wilson,A.K.; Rajan,S.S. \&Jonah,M. (2000). Bio- chemical pathway in cadmium toxicity .In :ZalupRK, Koropatnick J, Eds Molecular Biology and Toxicology of Metals. London :Taylor and Francis ;pp.1-74.

[4]. Byrav, D.S., B. Medhi, K;Vaiphei, A;Chakrabarti, K.L; Khanduja,(2010) .Comparative evaluation of different doses of green tea extract alone and in combination with sulfasalazinein experimentally induced inflammatory bowel disease in rats. Digestive Diseases and sciences ,56(5):1369 -78

[5]. Cabrera, C.;Gimenez ,R.\& Lopez, M.C.(2003).Determination of teacomponents with antioxidant activity .J. Agric. FoodChem., 51 (15) :4427-35.

[6]. Choi,j.H.;Chai,Y.M.;Joo,G.J.;Rhee,I.K.;Lee,I.S.;Kim,K.R.;Choi,M.S.\&Rhee,S.J.(2004).Effects of green tea catechin of morphonuclear leukocytes 5-lipoxygenase Activity, Leukotriene B4 synthesis and renal damage in diabetic rats.Ann.Nutr.Meat.,48:151-155.

[7]. Clark, T.A.;Heyliger,C. E.;Edel,A.L.; Goel,D.P.\&Pierce, G.N. (2004). Codelivery of a tea extract prevents morbidity and mortality associated with oral vanadate therapy in streptozotocin-InducedDiabetic Rats.Metabolism,153:(9) :11451151 .

[8]. Crespy,V.\&Williamson,G.(2004).Review of the health effect of green tea catechins in in vitro animalmodels. J.Nutr.,134 : 3431 s3440 s

[9]. Dunnick,J.K.\&Flower,B.A.(1988).Cadmium. In: lamming ,GE, Ed.Marshall's physiology of reproduction,1.New york:Churchill living stone ,Inc,pp.1-126.

[10]. Erba,D.;Riso;Patrizia;Bordoni,A.;Foti,P.;Biagi,P.L.\&Testolin,G.(2005). Effectiveness of moderate green tea consumption on antioxidative status and plasma lipid profile in humans.J. NutrBiochem,16:144-149.

[11]. Gayon,T.A.(1972).plant phenolic .olive and Boyed,Ed in boura.pp254.

[12]. Goyer,R.A.\&cherian,M.G.(1995).Renal effect of metals .In Metal Toxicology (R.A. Goyer, C.D. Klaassen and M.P. Waalkes, Eds.),pp389-412.Academic press, San Diego.

[13]. Habbeebu,S.;Liu,J.\&Klaassen,C.D.(1998).Cadmium-induced apoptosis in mouse liver.Toxicol Appl. Pharmacol.,149 (2):203-209.

[14]. Harstad,E.B.\&Klaassen,C.D.(2000).Analysis of strain difference in sensitivity to cadmium-induced hepatotoxicity in fischer344 and Sprague-Dawley Rats.Toxicol.Sci.,67:329.

[15]. Jaurp,L.;Berglund,M.;Elinder,C.G.;Nordberg,G.\&Vahter,M.(1998). Health effects of cadmium exposure-a review of the literature and a risk estimate .ScandJ.WorkEnviron.Health 24(suppl 1):1-51.

[16]. Jaurp,L.;Hellstrom,L.;Alfven,T.;Carlsson,M.D.;Grubb,A.;persson,B.;Pettersson,C.;Spang,G.;Schutz,A.\&Elinder,C.(2000).Low level exposure to cadmium and early kidney damage .theOSCAR study .OCCUP Environ.Med 57(10):668-672.

[17]. Jones,M.M.\&Cherian,M.G.(1988).The search for chelate antagonists for chronic cadmium intoxication.Toxicology,62:1-25.

[18]. Kim,J.H.;Kang,B.H.\&Jeong,J.M.(2003).Antioxidant antimutagenicand chemo preventive activities of a phyto-extract mixture derived from various vegetables ,Fruits and oriental herbs.FoodSci.Bio-Technol 12:631-638.

[19]. Klassen,C.D.;Liu,J.\&Choudhuri, S.(1999).Metallothionein:an intra-cellular protein to protect against cadmium toxicity. Annu.Rev. PharmacolToxicol 39:267-294

[20]. Kwag,O.G.;Kim,S.O.;Choi,„J.H.;Rhee,I.K.;Choi,M.S.\&Rhee , S.J.(2001).Vitamin E improves microsomal phospholipase A2 activity and the arachidonic acid cascade in kidney of diabetic rats.J.Nutr.131:1297-1301.

[21]. Lafuent,A.;Cano,P.\&Esquifino,A.( 2003).Are cadmium effects onplasma gonadotropins ,prolactin,ACTH,GH AND TSH level, dose -dependent?Bio metals ; 16:243-50.

[22]. Lafuente,A.;Marquez,N.;Perez;Lorenzo,M.;Pazo,D.\&Eequifino, A. I.(2000). Pubertal and post pubertal cadmium exposure differentially affects the hypothalamic - pituitary - testicularaxis function in the rat. Food Chem.Toxicol,38:913-923

[23]. Liao,S.;Kao,Y.H.\&Hiipakka,R.A.(2001).Green tea bio-chemical andbiological basis for health benefits.Vit.Horm.,62:1-94

[24]. Llobet,J.;Granero,S.;Torres,A.;Schuhmacher,M.\&Domingo,J. (1998).Biological monitoring of environ metal pollution and human exposure to metals in Tarragona, Spain III .Blood levels. Trace Elem Electr 15:76-80.

[25]. Luna,L.G.(1968).Manual of histological staining method of the armed institute of pathology. $3^{\text {rd }}$ edition.MC Graw. Hillbook. Co. London.

[26]. Manca,D.;Ricard,A.C.;Trottier,B.\&Chevalier,G.(1991).Studies on lipid peroxidation in rat tissues following administration of low and moderate doses of cadmium chloride .Toxicology;67:303-23.

[27]. May,T.W.\&Mckinney,G.L.(1981).Cadmium ,lead,mercury , arsenic and selenium concentrations in fresh water fish .Pesticide monitorJ.,15:14-38.

[28]. Obianime ,A.W.\&Robert,I.I.(2009).Antioxidants ,cadmium -induced toxicity ,serum biochemical and the histological abnormalities of the kidney and testes of male wisterrats. Nigerian J. physiolo.sci.24(2):177-185.

[29]. Obianime,A.W.;Aprioku,J.S.\&Ahiwe,N.J.(2011).Biochemical and hormonal effects of cadmium in female guinea pigs .J.Toxicol and Environ. Health sci.,3(2):39-43.

[30]. Sabu,M.C.;Smitha,K.\&Kuttan,R.(2002).Anti-diabetic activity of green tea polyphenols and their role in reducing oxidative stress in experimental diabetes J.Ethnopharmacol.83:109-116.

[31]. Saffari,Y\&Sadrzadeh,S.(2004).Green tea metabolite EGCG protects membranes against oxidative damage in vitro.Life Sci.,74:1513-1518

[32]. Schelfer,W.C.(1980).Statistics for the biological sciences. $2^{\text {nd }}$,ed., Addison.Wesley Publ.Comp.,California,London.

[33]. Silan,C.;Uzun,O.;Comunoglu,N.U.;Gokcen,S.;Bedirhan,S.\&Cengiz, M.(2007).Gentamicin -induced nephrotoxicity in ratsameliorated and healing effects of reveratol.Biol. Pharm. Bull.,30:79-83.

[34]. Skrzydlewsja,E.; Augustyniak, A.;Ostrowska,J. ;Luczaj,W.\&Tarasiuk, E.(2002).Green tea protection against aging -induced oxidative stress .Free Radic Biol.Med.,33:555.

[35]. Tariq,M.;Naveed,A.\&Barakat, K.(2010). The morphology characteristics and medicinal properties of "Camellia Sinensis" tea .J. Med. Plants Res.,4(19):2028-33.

[36]. Tokunagag ,S.; White, I.R.; Frost ,C.; Tanaka, K.; Kona, S.\&Tokudome, S. (2002).Green tea consumption and serum lipids lipoprotein in a population of healthy workersin Japan.Ann.Epidemiol.12:157-65.

[37]. Varga,B.;Paksy,K.\&Naray,M.(1991). Distribution of cadmium in ovaries , adrenals and pituitary gland after chronicadministration in rats. Acta physiol.Hung;78(3):221-6. 
[38]. Varnam,A.H.\&Sutherland,J.P.(1994).“Beverages :Technologychemistry and Microbiology”.London:Chapman\&Hall.

[39]. Wu,A.H.\&Yu,M.C.(2006).Tea ,hormone -related cancers and endrogenous hormone levels .Mol.Nutr.Food Res.,50(2):160-69.

[40]. Wu,S.M.;Shih,M.J.\&Ho,Y.C.(2007).Toxicological stress response and cadmium distribution in hybrid Tilapia (Oreochromis sp.)upon cadmium exposure .Comp. Biochem .Physiol.Toxicol.Pharmacol;145(2):218-26.

[41]. Yokozawa,T.;Nakagawa, T. Oya,T.;Okubo,T.\&Juneja,L. R.(2005).Green tea polyphenols and dietary fibre protect against kidney damage in rats with diabetic nephropathy.J. Pharmacol 57,773-78.

[42]. Zhang,M.H.;Luypaert,J.;Pierna,X.A.F.;Xu,Q.S.\&Massart, D. L. (2004).Determination of total antioxidant capacity in green tea by nearinfrared spectroscopy and multivariatecalibration.Talanta,62:25-35. 